\title{
EFFECT OF SEED PRIMING ON SEED VIGOR AND EARLY SEEDLING GROWTH IN MAIZE UNDER OPTIMAL AND SUBOPTIMAL TEMPERATURE CONDITIONS
}

\author{
Petar Čanak ${ }^{1 *}$, Milan Mirosavljević ${ }^{1}$, Mihajlo Ćirić1 ${ }^{1}$ Jelena Kešelj ${ }^{1}$, Bojana \\ Vujošević1, Dušan Stanisavljević ${ }^{1}$, Bojan Mitrović1
}

\begin{abstract}
Low temperature has a negative effect on germination parameters and early seedling growth. Seed priming is a beneficial pre-sowing treatment that partially hydrates the seeds to the point of germination process initiation, followed by drying which prevents radicle protrusion. The aim of this study was to evaluate the effect of different seed priming treatments on some maize seed vigor and early seedlings growth parameters at different temperature conditions. Seeds were primed in water (hydropriming) and $\mathrm{KNO}_{3}$ solution $(0,1 \%$ and $0,5 \%)$ at $25^{\circ} \mathrm{C}$ for $17 \mathrm{~h}$. Germination was tested at $25^{\circ} \mathrm{C}, 15 / 25^{\circ} \mathrm{C}$ and $15^{\circ} \mathrm{C}$. Seed priming treatments had more improving effects on studied seed and seedlings traits under suboptimal $\left(15^{\circ} \mathrm{C}\right.$ and $\left.15 / 25^{\circ} \mathrm{C}\right)$ than at optimal temperature conditions. Seed priming treatment with $0,5 \% \mathrm{KNO}_{3}$ had the most beneficial effects and increased the most of studied parameters under suboptimal conditions. Seed priming with $\mathrm{KNO}_{3}$ could be used to achieve higher seed vigor and seedling growth at suboptimal temperature conditions in maize.
\end{abstract}

Key words: Zea mays, hidropriming, $\mathrm{KNO}_{3}$ priming.

\section{Introduction}

Low temperature is one of the major environmental factor that has a significant influence on the growth and development of plants. The negative impact of low temperatures on plant metabolism can be detected from the cellular level to the level of the whole plant. The potential visual symptoms of chilling injuries in chilling-sensitive plants are leaf and hypocotyls wilting, the appearance of surface pits and large cavities, leaf necrosis, accelerated aging and the rupture of injured tissues, delayed, partial, or uneven ripening and growth decreasing. Low temperature stress disturbs cells ultrastructure, enzyme activity, mitochondrial respiratory activity and electron transport (Gay et al., 2008). The optimum temperature for the germination of maize seed

Originalni naučni rad (Original scientific paper)

${ }^{1}$ Čanak P., Mirosavljević M., Ćirić M., Kešelj J., Vujošević B., Stanisavljević D., Mitrović B., Institut za ratarstvo i povrtarstvo, Maksima Gorkog 30, Novi Sad.

*e-mail: petar.canak@ifvens.ns.ac.rs 
ranges from 25 to $28^{\circ} \mathrm{C}$. A stressful condition in germination lowers the plant population, which leads to reduction of grain yield (Radić et al., 2009). The negative effects of suboptimal temperature on maize germination parameters and early seedling growth has been previously reported. Saeidnejad et al. (2012) showed that low temperature decreased maize seed germination parameters, seedling emergence and growth. Low temperature had deleterious effect on membrane stability, relative water content, starch metabolism and antioxidant activities (Farooq et al., 2008a).

Different seed priming techniques can improve seed vigor and early seedlings growth. Seed priming is a beneficial presowing treatment that partially hydrates the seeds to the point of germination process initiation, followed by drying which prevents radicle protrusion. There are several priming techniques, such as hydropriming (Kaya et al., 2006), osmopriming (Foti et al., 2008), halopriming (Patade et al., 2012), matrix priming (Zhang et al., 2007) and biopriming (Begum et al., 2010). The two most commonly used seed priming methods are hydropriming and osmopriming. Hydropriming is easily available and uncostly pre-sowing treatment, where seed hydration is achieved by soaking seeds in water (Casenave and Toselli, 2007). Kaya et al. (2006) showed that hydropriming increased germination and seedling growth under salt and drought stress during germination in sunflower. Osmopriming is standard priming method that involves the use of adverse osmotic solution like mannitol, polyethylene glycol or salts such as chlorides, sulphates, nitrates to control water potential (Chen et al., 2010; Papastylianou and Karamanos, 2012). The usefulness of osmopriming with $\mathrm{KNO}_{3}$ was shown in different plant species (Kaya et al., 2006; Eskandari and Kazemi, 2011).
Positive effect of priming treatments is especially highlighted under suboptimal conditions. Farooq et al. (2008b) reported that seed priming treatment with salicylic acid induced chilling tolerance in maize. Also, Guan et al. (2009) showed that seed priming with chitosan improves maize germination and seedling growth in under low temperature stress.

The aim of this study was to evaluate the effect of different seed priming treatments on maize seed vigor and early seedlings growth at different temperature conditions.

\section{Material and methods}

Seed source was maize inbred line 21 NS Ht, developed at the Institute of Field and Vegetable Crops, Novi Sad. Seed priming treatments were conducted by soaking seed in water (hydropriming) or two different concentrations of $\mathrm{KNO}_{3}$ solution $(0,1 \%$ and $0,5 \%)$ at $25^{\circ} \mathrm{C}$ for $17 \mathrm{~h}$. Untreated maize seed was used as control. Following the treatment, seeds were dried at room temperature for a few days, to the original moisture. Germination was tested in double layer rolled filter paper $(30 \times 30 \mathrm{~cm})$ moistened with distilled water. One set of filter papers was placed at $25^{\circ} \mathrm{C}$ (optimal temperature), whereas the second set was kept at $15^{\circ} \mathrm{C}$ (low temperature) and the third one set was firstly placed at $15^{\circ} \mathrm{C}$ for half of the experiment period $(84 \mathrm{~h})$ and then placed at the optimal temperature, until the end of experiment. Testing was carried out in the dark, in four replicates, with 50 seeds per replicate. Filter paper rolls of filter paper were put in plastic bags to avoid moisture loss. Number of germinated seeds was recorded daily, for 7 days. Seeds were considered germinated when the radicle was $2 \mathrm{~mm}$ long.

Germination index (GI) was calculated 
according to THE ASSOCIATION OF OFFICIAL SEED ANALYSTS (1983) formula:

$\mathrm{GI}=$ No. of germinated seeds / Day of first count $+\ldots+$ No. of germinated seeds/Day of final count.

Coefficient of velocity of germination (CVG) was calculated according to formula (Kader and Jutzi, 2004):

\section{$\mathrm{CVG}=100 \times \Sigma \mathrm{Ni} / \Sigma \mathrm{Ti} \mathrm{Ni}$}

where $\mathrm{N}$ is the number of seeds germinated on day $\mathrm{i}$, and $\mathrm{Ti}$ is the number of counted days.

Seedlings vigor index (SVI) was calculated according to formula (Abdul Baki and Anderson, 1973):

$\mathrm{SVI}=$ seedling length $\mathrm{x}$ germination percentage

On the 7th day seedling root length (RL), shoot length (SL), root weight (RW) and shoot weight (SW) of 10 seedlings per replicate were recorded and averaged.

Data were processed using twoway analysis of variance, with software STATISTICA 12. Means were compared using Duncan's multiple range test.

\section{Results and discussion}

Under low temperature (Table 1) conditions seed priming treatments had significant effect on SVI and highly significant effects on CVG and GI. Priming treatments increased seed CVG, GI and SVI compared to the control. The most beneficial effect on $\mathrm{CVG}$ and $\mathrm{GI}$ had $0,5 \% \mathrm{KNO}_{3}$ treatment, which significantly increased both parameters in relation to control and the other two priming treatments. All priming treatments significantly increased SVI comparing to control, however, no significant differences between treatments were identified.Overall, under low temperature conditions, $0,5 \% \mathrm{KNO}_{3}$ can be singled out as the best priming protocol with the highest positive effect on studied vigor parameters.

Seedlings growth parameters (SL, RL, SW and RW) were differently influenced by priming treatments under low temperature conditions. The effect of seed treatments on SL was significant, while on the other parameters it was insignificant (RL, RW and SW). However, certain beneficial effects of seed priming were recorded in SW. Seed priming treatments did not have significant influence on root characteristics (RL and RW). Apart from statistically insignificant effect of priming, RL and RW had the highest value when seed had been treated with $0,5 \% \mathrm{KNO}_{3}$. All priming treatments increased the shoot length compared to the control, but between treatments significant difference was not detected. Although priming had no significant effect on root weight, seed treated with $0,5 \% \mathrm{KNO}_{3}$ had the highest weight. Priming treatment with $0,5 \% \mathrm{KNO}_{3}$ proved to be the most appropriate treatment for improving seedlings growth under low temperature conditions.

At mixed temperature, seed priming treatments had significant effects on seed CVG and GI, while there was no significant effect on SVI (Table 2). Significant difference between priming treatments in all three vigor parameters was not recorded.

Priming treatments didn't have improving effect on RW and RL under mixed temperature conditions, moreover, hydropriming had adverse effect on RW. SL and SW were significantly improved by seed treatments with both $\mathrm{KNO}_{3}$ solutions. All treatments increased shoot traits (SL and SW) compared to control. Significant difference was not detected between control and hydropriming. Treatment with $0,5 \% \mathrm{KNO}_{3}$ increased most of 
Table 1. The Influence of various seed priming treatments on the coefficient of velocity of germination (CVG), germination index (GI), seedlings vigor index (SVI), root length (RL), root weight (RW), shoot length (SL) and shoot weight (SW) at low temperature conditions $\left(15^{\circ} \mathrm{C}\right)$.

Tabela 1. Uticaj različitih prajminga semena na koeficijent brzine klijanja (CVG), indeks klijanja (GI), indeks vigora klijnaca (SVI), dužinu korena (RL), masa korena (RW), dužinu izdanka (SL) i masu izdanka (SW) pri uslovima nižih temperatura $\left(15^{\circ} \mathrm{C}\right)$.

\begin{tabular}{lccccccc}
\hline Treatment & CVG & GI & SVI & RL(cm) & RW(g) & SL(cm) & SW(g) \\
\hline Control & $16,6 \mathrm{c}$ & $43,0 \mathrm{c}$ & $181 \mathrm{~b}$ & $1,24 \mathrm{a}$ & $0,020 \mathrm{ab}$ & $0,74 \mathrm{~b}$ & $0,024 \mathrm{~b}$ \\
Hydropriming & $17,5 \mathrm{~b}$ & $55,9 \mathrm{~b}$ & $215 \mathrm{a}$ & $1,47 \mathrm{a}$ & $0,021 \mathrm{ab}$ & $0,87 \mathrm{a}$ & $0,025 \mathrm{ab}$ \\
$0,1 \% \mathrm{KNO}_{3}$ & $17,5 \mathrm{~b}$ & $57,8 \mathrm{~b}$ & $217 \mathrm{a}$ & $1,48 \mathrm{a}$ & $0,018 \mathrm{~b}$ & $0,87 \mathrm{a}$ & $0,025 \mathrm{ab}$ \\
$0,5 \% \mathrm{KNO}_{3}$ & $18,1 \mathrm{a}$ & $65,9 \mathrm{a}$ & $227 \mathrm{a}$ & $1,49 \mathrm{a}$ & $0,022 \mathrm{a}$ & $0,89 \mathrm{a}$ & $0,029 \mathrm{a}$ \\
$\mathrm{F} \mathrm{pr}$ & $<0,001$ & $<0,001$ & 0,036 & 0,148 & 0,136 & 0,012 & 0,103 \\
\hline
\end{tabular}

Different letters indicate significant difference at $\mathrm{P}<0,05$ level.

the observed indicators of seedling growth in relation to hydropriming and control.

The effect of priming treatments on all studied maize vigor and seedlings growth parameters was not significant when tested at $25^{\circ} \mathrm{C}$ (Table 3). All priming treatments reduced root length in comparison to control (significantly in the case of $0,5 \% \mathrm{KNO}_{3}$ ) and increased SL.

As a result of the uneven effects of priming solution on the growth and germination of maize at $25{ }^{\circ} \mathrm{C}$, optimal priming solution cannot be singled out.
Low temperature is the most limiting environmental factor that restricts wide global production of plants that originated from tropical regions. Considering that corn can be classified as a low temperature sensitive plant, its distribution is also limited by this factor. As a result of low temperatures during early sowing date of maize, uneven growth and germination is common occurrence. Because of that, maize is often planted later, which can have a negative impact on grain yield.

Seed germination and seedling growth could be improved with various pre-sowing methods such as priming. Priming has been

Table 2. The influence of various seed priming treatments on the coefficient of velocity of germination (CVG), germination index (GI), seedlings vigor index (SVI), root length $(R L)$, root weight $(R W)$, shoot length (SL) and shoot weight $(\mathrm{SW})$ at mixed temperature conditions $\left(15 / 25^{\circ} \mathrm{C}\right)$.

Tabela 2. Uticaj različitih prajminga semena na koeficijent brzine klijanja (CVG), indeks klijanja (GI), indeks vigora klijnaca (SVI), dužinu korena (RL), masu korena (RW), dužinu izdanka (SL) i masu izdanka (SW) pri uslovima kombinovanih temperatura $\left(15 / 25^{\circ} \mathrm{C}\right)$.

\begin{tabular}{lrrrrrrr}
\hline Treatment & CVG & GI & SVI & RL(cm) & RW(g) & SL(cm) & SW(g) \\
\hline Control & $17,9 \mathrm{~b}$ & $65,7 \mathrm{~b}$ & $972 \mathrm{a}$ & $7,02 \mathrm{a}$ & $0,130 \mathrm{a}$ & $3,16 \mathrm{c}$ & $0,100 \mathrm{c}$ \\
Hydropriming & $18,2 \mathrm{a}$ & $74,5 \mathrm{a}$ & $1021 \mathrm{a}$ & $7,28 \mathrm{a}$ & $0,113 \mathrm{~b}$ & $3,38 \mathrm{bc}$ & $0,103 \mathrm{bc}$ \\
$0,1 \% \mathrm{KNO}_{3}$ & $18,3 \mathrm{a}$ & $71,4 \mathrm{a}$ & $1046 \mathrm{a}$ & $7,29 \mathrm{a}$ & $0,129 \mathrm{a}$ & $3,57 \mathrm{ab}$ & $0,114 \mathrm{ab}$ \\
$0,5 \% \mathrm{KNO}_{3}$ & $18,4 \mathrm{a}$ & $75,9 \mathrm{a}$ & $1050 \mathrm{a}$ & $7,18 \mathrm{a}$ & $0,143 \mathrm{a}$ & $3,80 \mathrm{a}$ & $0,119 \mathrm{a}$ \\
$\mathrm{F} \mathrm{pr}$ & $<0,001$ & 0,008 & 0,386 & 0,805 & 0,011 & 0,011 & 0,024 \\
\hline
\end{tabular}

Different letters indicate significant difference at $\mathrm{P}<0,05$ level. 
proven to be an effective method for improving the parameters of germination and early seedling growth, particularly under suboptimal conditions like low temperature. Maize sowing in Serbia is carried out in early spring. During this period it often comes to sudden weather changes and temperatures drop. That is why seed priming treatments could be applied to overcome the negative impact of cold temperatures and stimulate the growth of seedlings.

Several methods and mathematical expressions were developed in order to describe germination process. GI, CVG and VI are one of the common measures of germination process. Germination index is used to predict relative vigor of samples with the same quantity of germinated seeds. Seeds with high

Table 3. The influence of various seed priming treatments on the coefficient of velocity of germination (CVG), germination index (GI), seedlings vigor index (SVI), root length (RL), root weight (RW), shoot length (SL) and shoot weight (SW) at optimal temperature conditions $\left(25^{\circ}\right)$.

Tabela 3. Uticaj različitih prajminga semena na koeficijent brzine klijanja (CVG), indeks klijanja (GI), indeks vigora klijnaca (SVI), dužinu korena (RL), masu korena (RW), dužinu izdanka (SL) i masu izdanka (SW) pri uslovima optimalnih temperatura $\left(25^{\circ} \mathrm{C}\right)$.

\begin{tabular}{lcccccll}
\hline Treatment & CVG & GI & SVI & RL(cm) & RW(g) & SL(cm) & SW(g) \\
\hline Control & $21,8 \mathrm{a}$ & $141,7 \mathrm{a}$ & $1628 \mathrm{a}$ & $11,48 \mathrm{a}$ & $0,1853 \mathrm{a}$ & $5,64 \mathrm{~b}$ & $0,191 \mathrm{a}$ \\
Hydropriming & $22,0 \mathrm{a}$ & $150,4 \mathrm{a}$ & $1613 \mathrm{a}$ & $10,52 \mathrm{ab}$ & $0,1843 \mathrm{a}$ & $6,005 \mathrm{ab}$ & $0,206 \mathrm{a}$ \\
$0,1 \% \mathrm{KNO}_{3}$ & $22,0 \mathrm{a}$ & $147,1 \mathrm{a}$ & $1585 \mathrm{a}$ & $10,39 \mathrm{ab}$ & $0,1855 \mathrm{a}$ & $6,305 \mathrm{a}$ & $0,214 \mathrm{a}$ \\
$0,5 \% \mathrm{KNO}_{3}$ & $21,9 \mathrm{a}$ & $147,8 \mathrm{a}$ & $1413 \mathrm{a}$ & $8,85 \mathrm{~b}$ & $0,164 \mathrm{a}$ & $5,873 \mathrm{ab}$ & $0,192 \mathrm{a}$ \\
$\mathrm{F} \mathrm{pr}$ & 0,216 & 0,220 & 0,282 & 0,073 & 0,276 & 0,154 & 0,238 \\
\hline
\end{tabular}

Different letters indicate significant difference at $\mathrm{P}<0,05$ level.

germination index have high seed vigor and can produce vigorous seedlings with a high performance. CVG represents the rapidity of germination, and CVG values increase due to the increased number of germinated seed and the decrease in germination time. Seed priming treatments had positive effects on these seed vigor parameters, in particular in suboptimal conditions where this effect was statistically significant. These results are in agreement with results of Afzal et al. (2012), which showed that the priming with moringa leaf extract improved GI and other germination parameters and seedling growth at low temperature. Fuller and Hamza (2013) showed that seed priming treatments increased CVG, GI and other seed vigor parameters and seedling growth of wheat seed. SVI was improved by seed priming only at low temperature. This parameter was computed by multiplying the germination percentage and seedling length. In this research, there was no difference in germination at any temperature (data not shown). Because of that, SVI depended mostly on seedling growth. Kalsa and Abebie (2012) reported that SVI could be improved with certain $\mathrm{KNO}_{3}$ priming treatments in Vicia villosa.

Besides the speed of seed germination, root and shoot length and weight are important contributors to seed vigor. Plants have direct contact with the soil medium through the roots and due to that root weight and length are important indicators of plant response to stress. Low temperature decreased root length and weight compared to optimal conditions. Priming treatments have improved seedling traits in most cases at suboptimal conditions. Afzal et al. (2008) reported that various seed 
priming treatments increased maize seedling fresh and dry weight, germination percent and germination index under cool condition. Seed priming with $\mathrm{CaCl}_{2}$ reduced the chilling damage significantly and increased root and shoot length, seedling fresh and dry weights, germination rate parameters, and antioxidative enzyme activity in maize (Farooq et al., 2008a). Treatment with $0,5 \% \mathrm{KNO}_{3}$ improved roots traits under suboptimal conditions (at $15^{\circ} \mathrm{C}$, and $15 / 25^{\circ} \mathrm{C}$ ), while, in contrast, at optimal condition it had slightly reduced root traits. Seed priming had beneficial effect on seedling growth at suboptimal temperature, while, at the optimal one the effect of priming was absent, probably because of the fact that seedling already reached their maximal growth. Occurrence that priming treatment with $\mathrm{KNO}_{3}$ had adverse effect on some seedlings traits is consistent with earlier work of Basra et al. (2006), in which they showed that seed treatment with $\mathrm{KNO}_{3}$ decreased shoot length in rice. According to Singh and Gill (1988), in wheat $\mathrm{KNO}_{3}$ toxicity results in damage to the cellular organelles and membranes. In contrast, Tzortzakis (2009) showed that seed priming treatment with $\mathrm{KNO}_{3}$ enhanced shoot and root fresh weight in endive and chicory.

\section{Conclusion}

The results showed that suboptimal temperatures had negative effects on seed vigor and early seedlings growth. Seed priming treatments had more improving effects on studied seed and seedlings traits under suboptimal (low and mixed temperature) than at optimal conditions. Seed priming treatment with $0,5 \% \mathrm{KNO}_{3}$ had the most beneficial effects and increased all studied parameters under suboptimal conditions. Therefore, seed priming with $\mathrm{KNO}_{3}$ can be used to achieve better seedlings growth at suboptimal temperature conditions in maize.

\section{Acknowledgements}

This paper presents the results of the project TR1661056, supported by The Ministry of Education, Science and Technological Development of Republic Serbia.

\section{References}

Abdul Baki AA and Anderson JD (1973): Vigour determination in soybean seed by multiple criteria. Crop Sci. 13: 630633.

Afzal I, Basra SMA, Shahid M, Farooq M, Saleem M (2008): Priming enhances germination of spring maize (Zea mays L.) under cool conditions. Seed Sci. Technol. 36: 497-503.

Afzal I, Hussain B, Basra SMA, Rehman H (2012): Priming with moringa leaf extract reduces imbibitional chilling injury in spring maize. Seed Sci. Technol. 40: 271-276.

Basra SMA, Farooq M, Tabassum R, Ahmed N (2006): Evaluation of seed vigour enhancement techniques on physiological and biochemical basis in coarse rice. Seed Sci. Technol. 34: 719728.

Begum MM, Sariah M, Puteh AB, Zainal Abidin MA, Rahman MA, Siddiquai (2010): Field performance of bioprimed seeds to suppressColletotrichum truncatum causing damping-off and seedling stand of soybean. Biological Control. 53(1): 18-23.

Casenave EC and Toselli ME (2007): 
Hydropriming as a pre-treatment for cotton germination under thermal and water stress conditions. Seed Sci. Technol. 35: 88-98.

Chen K, Arora R, Arora U (2010): Osmopriming of spinach (Spinacia oleracea L. cv. Bloomsdale) seeds and germination performance under temperature and water stress. Seed Sci. Technol. 38: 3648.

Foti R, Abureni K, Tigere A, Gotosa J, Gere J (2008): The efficacy of different seed priming osmotica on the establishment of maize (Zea mays L.) caryopses. J. Arid. Environ. 72: 1127-1130.

Gay C, Kaplan F, Kopka J, Selbig J, Hincha DK (2008): Metabolomics of temperature stress. Physiol. Plant. 132: 220-235.

Eskandari H and Kazemi K (2011): Effect of seed priming on germination properties and seedling establishment of cowpea (Vigna sinensis). Not. Sci. Biol. 3(4): 113-116.

Farooq M, Aziz T, Basra SMA, Wahid A, Khaliq A, Cheema MA (2008a): Exploring the role of calcium to improve chilling tolerance in hybrid maize. J. Agron. Crop Sci. 194: 350-359.

Farooq M, Aziz T, Basra SMA, Cheema MA, Rehman H (2008b): Chilling tolerance in hybrid maize induced by seed priming with salicylic acid. J. Agron. Crop Sci. 194: 161-168.

Fuller MP and Hamza JH (2013): Effect of osmotic potential of activator solution and temperature on viability and vigour of wheat seed. Afr. J. Agric. Res. (in press, https://core.ac.uk/download/ files/295/29817567.pdf)

Guan YJ, Hu J, Wang XJ, Shao CX (2009): Seed priming with chitosan improves maize germination and seedling growth in relation to physiological changes under low temperature stress. J. Zhejiang Univ. Sci. B. 10:427-33.

Kader MA and Jutzi SC (2004): Effects of thermal and salt treatments during imbibition on germination and seedling growth of sorghum at $42 / 19^{\circ} \mathrm{C}$. J. Agron. Crop Sci. 190: 35-38.

Kalsa KK and Abebie B (2012): Influence of seed priming on seed germination and vigor traits of Vicia villosa ssp. dasycarpa (Ten.). Afr. J. Agric. Res. 7(21): 3202-3208.

Kaya MD, Okcu G, Atak M, Cikili Y, Kolsarici O (2006): Seed treatments to overcome salt and drought stress during germination in sunflower (Helianthus annuus L.). Europ. J. Agron. 24: 291295.

Papastylianou PT and Karamanos AJ (2012): Effect of osmopriming treatments with mannitol on cotton seed germination performance under suboptimal conditions. Seed Sci. Technol.40: 248258.

Patade VY, Bhargava S, Suprasanna P (2012): Halopriming mediated salt and isoosmotic PEG stress tolerance and, gene expression profiling in sugarcane (Saccharum officinarum L.). Mol. Biol. Rep. 39: 9563-9572.

Radić V, Mrđa J, Marjanović-Jeromela A, Prole S, Jokić G, Marinković R, Miklič V (2009): Corn seedling sensitivity on stressful conditions. Selekcija i semenarstvo. 15 (4): 21-27.

Saeidnejad AH, Pouramir F, Naghizadeh M (2012): Improving chilling tolerance of maize seedlings under cold conditions by spermine application. Not. Bot. Sci. 4: 110-117.

Singh H and Gill HS (1988): Effect seed 
treatment with salts on germination and yield of wheat. Agric. Sci. Digest. 8:173-175.

The Association of Official Seed Analysts (1983): Seed Vigor Testing Handbook. Contribution No. 32 to the Handbook on Seed Testing.Association of Official Seed Analysis, Springfield, IL.

Tzortzakis NG (2009): Effect of pre-sowing treatment on seed germination and seedling vigour in endive and chicory. Hort. Sci. 36: 117-125.

Zhang CF, Hu J, Lou J, Zhang Y, Hu WHM (2007): Sand priming in relation to physiological changes in seed germination and seedling growth of waxy maize under high-salt stress Seed Sci. Technol. 35: 733-738. 


\title{
EFEKAT PRAJMINGA SMENA NA VIGOR I POČETNI PORAST KLIJANACA KUKURUZA PRI OPTIMALNIM I SUBOPTIMALNIM TEMPERATURNIM USLOVIMA
}

\author{
Petar Čanak, Milan Mirosavljević, Mihajlo Ćirić, Jelena Kešelj, \\ Bojana Vujošević, Dušan Stanisavljević, Bojan Mitrović
}

\begin{abstract}
Sažetak
Niske temperature imaju negativan uticaj na parametre klijanja i početni porast klijanca. Prajming semena predstavlja tretman kojim se seme delimično hidrira tako da se inicira proces klijanja, a zatim suši kako bi se klijanje zaustavilo pre izbijanja korenka iz semena. Cilj ovog eksperimenta bio je da se ispita uticaj različitih prajming tretmana na vigor i porast klijanca kukuruza u različitim temperaturnim uslovima. Prajming semena izvršen je sa vodom (hidroprajming) i $\mathrm{KNO}_{3}$ rastvorom $(0,1 \%$ i $0,5 \%)$ na temperaturi $25^{\circ} \mathrm{C}$ u trajanju od $17 \mathrm{~h}$. Seme je naklijavano na $25^{\circ} \mathrm{C}, 15 / 25^{\circ} \mathrm{C}$ i $15^{\circ} \mathrm{C}$. Pozitivniji efekat prajminga utvrđen je pri suboptimalnim $\left(15^{\circ} \mathrm{C}\right.$ i $\left.15 / 25^{\circ} \mathrm{C}\right)$ nego pri optimalnim temperaturnim uslovima. Kao najbolji, pokazao se tretman sa rastvorom $0,5 \% \mathrm{KNO}_{3}$ uvećavši posmatrane parametre na suboptimalnoj temperaturi. Ovi rezultati ukazuju da je primenom prajminga sa rastvorom $\mathrm{KNO}_{3}$ moguće poboljšati vigor semena $\mathrm{i}$ početni porast ponika kukuruza pri suboptimalnim temperaturama, odnosno, obezbediti sigurnije nicanje pri ranim rokovima setve.
\end{abstract}

Key words: Zea mays, hidroprajming, $\mathrm{KNO}_{3}$ prajming.

Primljen: 04. 05. 2016. Prihvaćen: 25.05.2016. 